eJKI | Vol. 9, No. 1, Maret 2020

Jurnal Kesehatan Islam

e-ISSN : 2615-8345

Publikasi oleh Fakultas Kedokteran, Universitas Islam Malang

Email: jkesislam@unisma.ac.id

Home Page : http://riset.unisma.ac.id/index.php/jki

\title{
EFEK EKSTRAK ETANOL DAUN GEDI MERAH (Abelmoschus manihot (L.) Medik) TERHADAP KADAR SOD DAN MDA PADA AORTA TIKUS MODEL DIABETES MELITUS TIPE 2
}

\author{
Hendra Putra Sanjaya, Fathia Annis Pramesti, Yudi Purnomo*
} Fakultas Kedokteran Universitas Islam Malang

*Corresponding author email : yudi.purnomo@unisma.ac.id

MT. Haryono 193 Malang, Jawa Timur, Indonesia, 65144 Tel. (0341) 558959

ABSTRAK

Pendahuluan: Hiperglikemia pada diabetes melitus (DM) meningkatkan produksi reactive oxygen species (ROS) yang berperan terhadap komplikasi makroangiopati diabetik. Daun gedi merah dikenal memiliki efek antioksidan dan antihiperglikemia sehingga diharapkan dapat menghambat kerusakan oksidatif pada DM. Penelitian ini bertujuan untuk mengetahui efek ekstrak etanol daun gedi merah dalam mencegah kerusakan oksidatif pada DM dengan mengamati kadar Superoxide Dismutase (SOD) dan Malondialdehyde (MDA) aorta tikus model DM.

Metode: Tikus Sprague Dawley jantan berusia 4-6 minggu dikelompokkan menjadi 2 kelompok kontrol dan 3 kelompok perlakuan ( $\mathrm{n}=5$ ekor). Hewan coba diinduksi diet tinggi lemak-fruktosa (DTLF) dan Stretpzotocin (STZ) $25 \mathrm{mg} / \mathrm{kgBB}$ intraperitoneal multiple dose. Selanjutnya kelompok perlakuan diberikan ekstrak etanol daun Gedi merah (EEDGM) dosis $200 \mathrm{mg} / \mathrm{kgBB}, 400 \mathrm{mg} / \mathrm{kgBB}$ dan $800 \mathrm{mg} / \mathrm{kgBB}$. Pengukuran kadar SOD dan MDA aorta menggunakan Elisa SOD rat kit dan Elisa MDA rat kit. Analisa data menggunakan One Way Anova dilanjutkan dengan uji BNT ( $p<0,05)$.

Hasil: Pemberian EEDGM dosis $200 \mathrm{mg} / \mathrm{kgBB}, 400 \mathrm{mg} / \mathrm{kgBB}$ dan $800 \mathrm{mg} / \mathrm{kgBB}$ menghambat penurunan kadar SOD aorta berturut-turut sekitar 10\%, 30\% dan 50\% dibandingkan kelompok kontrol diabetes melitus (KDM) $(p<0,05)$ sementara kadar MDA aorta diturunkan kurang lebih sekitar 20\%, 40\%, dan 70\% ( $p<0,05)$. Induksi DTLF dan STZ pada kelompok KDM menurunkan kadar SOD aorta 50\% dan meningkatkan MDA aorta 2 kali lipat dibandingkan $\mathrm{KN}(p<0,05)$.

Kesimpulan: Pemberian EEDGM 200 - $800 \mathrm{mg} / \mathrm{kgBB}$ menghambat penurunan kadar SOD aorta dan menghambat peningkatan kadar MDA aorta tikus model DM.

Kata Kunci : streptozotocin, diet tinggi lemak, diet tinggi fruktosa, stres oksidatif, diabetes

\section{EFFECT ETHANOL EXTRACT OF Abelmoschus manihot (L.) Medik ON THE LEVELS OF SOD AND MDA FOUND IN THE AORTA OF MODEL RATS WITH DIABETES MELLITUS TYPE 2}

\begin{abstract}
Introduction: Hyperglycemia in diabetes mellitus (DM) increases the production of reactive oxygen species (ROS) which plays a role in complications of diabetic macroangiopathy. Abelmoschus manihot (L.) Medik are known to have antioxidant and antihyperglycemic effects so they are expected to inhibit oxidative damage in DM. This study aims to determine the effect of the ethanol extract of aibika eaves in preventing oxidative damage in DM by observing the levels of Superoxide Dismutase (SOD) and Malondialdehyde (MDA) in the aorta of rats with DM.

Methods: Male Sprague Dawley rats aged 4-6 weeks were grouped into 2 control groups and 3 treatment groups namely the ethanol extract group of Abelmoschus manihot (L.) Medik ( $\mathrm{n}=5$ heads). The experimental animals were induced with high-fat-fructose diet (HFFD) and Streptozotocin (STZ) $25 \mathrm{mg} / \mathrm{kgBW}$ intraperitoneal multiple doses. Furthermore, Ethanol extract of Abelmoshus manihot (L.) Medik $200 \mathrm{mg} / \mathrm{kg}, 400 \mathrm{mg} / \mathrm{kg}$ and $800 \mathrm{mg} / \mathrm{kg}$ were given. The measurement of aortic SOD and MDA levels used the Elisa SOD rat kit and Elisa MDA rat kit. Data analysis using One Way Anova followed by LSD test $(\mathrm{p}<0.05)$.

Results: The administration of Ethanol extract of Abelmoshus manihot (L.) Medik at the doses of $200 \mathrm{mg} / \mathrm{kg}, 400$ $\mathrm{mg} / \mathrm{kg}$ and $800 \mathrm{mg} / \mathrm{kg}$ of body weight inhibited the decrease in aortic SOD levels of about $10 \%, 30 \%$ and $50 \%$ respectively compared to the KDM group ( $\mathrm{p}<0.05$ ) while the aortic MDA levels decreased by approximately $20 \%$, $40 \%$, and $70 \%(\mathrm{p}<0.05)$. The induction of DTLF and STZ in the KDM group decreased aortic SOD levels 50\% and increased aortic MDA 2 times compared to $\mathrm{KN}(\mathrm{p}<0.05)$.

Conclusion: Ethanol extract of Abelmoshus manihot (L.) Medik 200-800 mg/kgBW inhibited the decrease in aortic SOD levels and inhibited the increase in aortic MDA levels in DM-model rat.
\end{abstract}

Keywords: streptozotocin, high fat diet, high fructose diet, oxidative stress, diabetes 


\section{PENDAHULUAN}

Komplikasi makroangiopati diabetes masih menjadi permasalahan kesehatan di Indonesia. Makroangiopati diabetik adalah abnormalitas dari sel endotel pembuluh darah besar seperti aorta dan arteri koroner akibat tingginya kadar glukosa darah ${ }^{1}$. Penyakit jantung koroner (PJK) adalah salah satu komplikasi makroangiopati dengan prevalensi kejadian sebesar 1,5\% pada pasien Diabetes Melitus (DM) di Indonesia. Komplikasi Makroangiopati merupakan penyebab kematian utama pada pasien Diabetes Melitus dengan angka kematian sebesar 7,4 juta per tahun ${ }^{2}$. Kondisi stress oksidatif berperan terhadap timbulnya komplikasi makroangiopati pada DM. Kondisi hiperglikemi pada pasien DM dapat meningkatkan produksi Reactive Oxygen Species $(\mathrm{ROS})^{3}$.

Peningkatan ROS tanpa diimbangi dengan pertahanan antioksidan yang memadai menimbulkan kondisi stress oksidatif ${ }^{4}$. Peningkatan produksi ROS memicu antioksidan endogen lini pertama yaitu Superoxide Dismutase (SOD) untuk mengkatalisis radikal anion superoksida. Kondisi stress oksidatif ditandai penurunan kadar SOD akibat peningkatan jumlah ROS yang harus dinetralkan serta kerusakan pada tempat produksinya ${ }^{5}$. Stress oksidatif juga memicu peroksidasi lipid di membran sel dan menghasilkan produk akhir yang tidak stabil berupa Malondialdehida (MDA) ${ }^{6}$. Peroksidasi lipid pada membran sel menimbulkan gangguan permeabilitas membran sel, sehingga meningkatkan risiko terjadinya jejas dan kematian $\operatorname{sel}^{7}$. Kondisi stres oksidatif yang ditandai dengan peningkatan kadar MDA menimbulkan kerusakan oksidatif jaringan yang berperan terhadap terjadinya komplikasi makroangiopati diabetik. Penggunaan oral anti diabetik (OAD) sering digunakan untuk mengendalikan kadar glukosa pasien DM dan mengendalikan komplikasi makroangiopati. Namun OAD masih memiliki efek samping obat yang tidak diinginkan seperti gangguan pencernaan, peningkatan berat badan, dan hipoglikemia. Efek samping dari OAD mendorong pencarian sumber obat yang berasal dari alam ${ }^{8}$.

Gedi merah (Abelmoschus manihot L. Medik) merupakan bahan alam yang memiliki bahan aktif yang berkhasiat untuk pengobatan. Tanaman Gedi merah digunakan masyarakat untuk pengobatan kencing manis, keradangan, dan tekanan darah tinggi ${ }^{8}$. Pada uji preklinik, daun Gedi merah terdapat kandungan senyawa flavonoid, alkaloid, saponin, dan tanin yang bekerja sebagai antidiabetik. Hingga saat ini penelitian tentang Gedi merah (Abelmoschus manihot L. Medik) untuk menghambat komplikasi makroangiopati pada DM belum pernah dilakukan. Berdasarkan latar belakang diatas perlu dilakukan pengujian ekstrak daun gedi merah untuk menghambat makroangiopati diabetik dengan mengamati kadar SOD dan MDA pada jaringan aorta.

\section{METODE}

Penelitian ini menggunakan metode eksperimental laboratorium secara in vivo dengan control group post test only design. Penelitian ini telah mendapat persetujuan etik dari komite etik penelitian Universitas Brawijaya dengan nomor No. 028-KEP UB tahun 2020. Penelitian dilakukan di Laboratorium Farmakologi dan Laboratorium Biokimia Fakultas Kedokteran Universitas Brawijaya. Penelitian ini menggunakan hewan coba tikus jantan galur sprague dawley. Usia tikus 4-6 minggu dengan berat badan sekitar 180-200 gram. Tikus dibagi menjadi 2 kelompok kontrol yang terdiri dari $\mathrm{KN}$ dan $\mathrm{KDM}$, serta 3 kelompok perlakuan yakni kelompok EEDGM $200 \mathrm{mg} / \mathrm{kgBB}$, EEDGM $400 \mathrm{mg} / \mathrm{kgBB}$, dan EEDGM 800 $\mathrm{mg} / \mathrm{kgBB}$.

\section{Pembuatan Tikus Model Diabetes Melitus}

Setelah tikus dilakukan aklimatisasi selama 7 hari, kelompok perlakuan dan kelompok kontrol DM diberikan diet tinggi lemak fruktosa (DTLF) dan induksi streptozotocin (STZ). DTLF terdiri dari kuning telur (4\%), minyak kambing $(6,5 \%)$, minyak babi $(6,5 \%)$, asam kolat $(0,2 \%)$, pakan ayam $(82,8 \%)$, dan air secukupnya yang diberikan 25 gram/hari setiap sore ${ }^{9}$. Pemberian fruktosa $20 \%$ terdiri dari $200 \mathrm{ml}$ fruktosa dicampur kedalam 1000 $\mathrm{ml}$ air. Fruktosa diberikan $40 \mathrm{ml} /$ hari ad libitum. Induksi STZ dilakukan setelah memasuki minggu ke-4 pemberian DTLF, dengan dosis STZ sebanyak $25 \mathrm{mg} / \mathrm{kgBB}$ secara intraperitoneal multiple dose. Pengukuran kadar gula darah puasa dilakukan 72 jam pasca injeksi ${ }^{10}$.

\section{Pembuatan Ektrak Etanol Daun Gedi Merah}

Serbuk Daun Gedi Merah (Abelmoschus manihot (L.) Medik) diperoleh dari Balai Materia Medika, Batu, Jawa Timur, dengan surat keterangan determinasi nomer 074/193A /102.7/2020. Ekstraksi daun gedi merah menggunakan metode soxhletasi dengan serbuk daun gedi merah sebanyak 25 gram dalam etanol 96\%. Proses ekstraksi dihentikan sampai 6 siklus atau pelarut berkurang kepekatannya. Hasil ekstraksi diuap dengan rotary evaporator untuk mendapatkan bentuk pasta. Ekstrak disuspensi dengan CMC-Na 0,1\% sebelum diberikan . Dosis ekstrak etanol daun gedi merah dibagi menjadi 3 yaitu $200 \mathrm{mg} / \mathrm{kgBB}, 400$ $\mathrm{mg} / \mathrm{kgBB}$,dan $800 \mathrm{mg} / \mathrm{kgBB}^{6}$.

\section{Pengorbanan hewan coba dan preparasi Sampel \\ Pengorbanan hewan coba diawali dengan} anastesi menggunakan ketamin $0,2 \mathrm{ml}$ yang diinjeksikan secara intramuskuler, kemudian tikus dibedah secara vertikal mengikuti linea media dari arah abdomen menuju thorax untuk diambil organ Aorta. Aorta dibilas menggunakan larutan Natrium Cloride $(\mathrm{NaCl})$. Aorta ditimbang dengan berat sekitar $100 \mathrm{mg}$. Sampel dibilas menggunakan larutan Phosphate Buffer Saline (PBS) kemudian 
dihancurkan menggunakan mortar dan ditambahkan cairan buffer SOD untuk pemeriksaan SOD dan cairan PBS untuk pemeriksaan MDA dengan perbandingan 1:10. Sampel yang telah larut dimasukkan dalam tabung microtube $1,5 \mathrm{ml}$ dan dicentrifuge dalam $4000 \mathrm{rpm}$ selama 15 menit untuk mendapatkan supernatan.

\section{Pengukuran Kadar SOD dan MDA Aorta}

Pengukuran kadar SOD dan MDA aorta menggunakan elisa rat kit Elabscience dengan nomor katalog E-EL-R1424 untuk SOD dan E-EL0060 untuk MDA, pengukuran kadar sesuai dengan pedoman pada kit tersebut. Larutan standar atau sampel sebanyak $50 \mu \mathrm{L}$ dimasukan kedalam well kemudian ditambahkan Biotinylated Detection $A b$ sebanyak $50 \mu \mathrm{L}$, campuran diinkubasi pada suhu $37^{\circ} \mathrm{C}$ selama 45 menit kemudian diaspirasi. Larutan wash buffer ditambahkan sebanyak $350 \mu \mathrm{L}$ dan dicuci 3 kali. Setelah itu, HRP Conjugate Working
Solution $100 \mu \mathrm{L}$ ditambahkan dan diinkubasi pada suhu $37^{\circ} \mathrm{C}$ selama 30 menit, diaspirasi dan dicuci 5 kali. Selanjutnya, substrat reagent ditambahkan sebanyak $90 \mu \mathrm{L}$ dan diinkubasi pada suhu $37{ }^{\circ} \mathrm{C}$ selama 15 menit. Stop solution ditambahkan sebanyak $50 \mu \mathrm{L}$. Nilai absorbansi sampel diukur menggunakan microplate reader pada $\lambda=450 \mathrm{~nm}$. Dilakukan regresi linier dengan nilai absorbansi standar, kemudian nilai absorbansi sampel diukur menggunakan kurva standar dengan satuan ng/mL.

\section{Analisa Data}

Data yang diperoleh dilakukan uji normalitas dan homogenitas, kemudian dilakukan uji beda menggunakan one way ANOVA dan dilanjutkan uji least significance different (LSD) untuk mengetahui perbandingan antar perlakuan. Hasil dinyatakan bermakna apabila nilai $p<0,05$. Analisa data dilakukan dengan memakai software statistik SPSS.

\section{Karaktristik Sampel}

\section{HASIL DAN ANALISA DATA}

Pada penelitian ini didapatkan hasil karakteristik hewan coba yang tercantum dalam tabel 1. Tabel 1. Karakteristik sampel

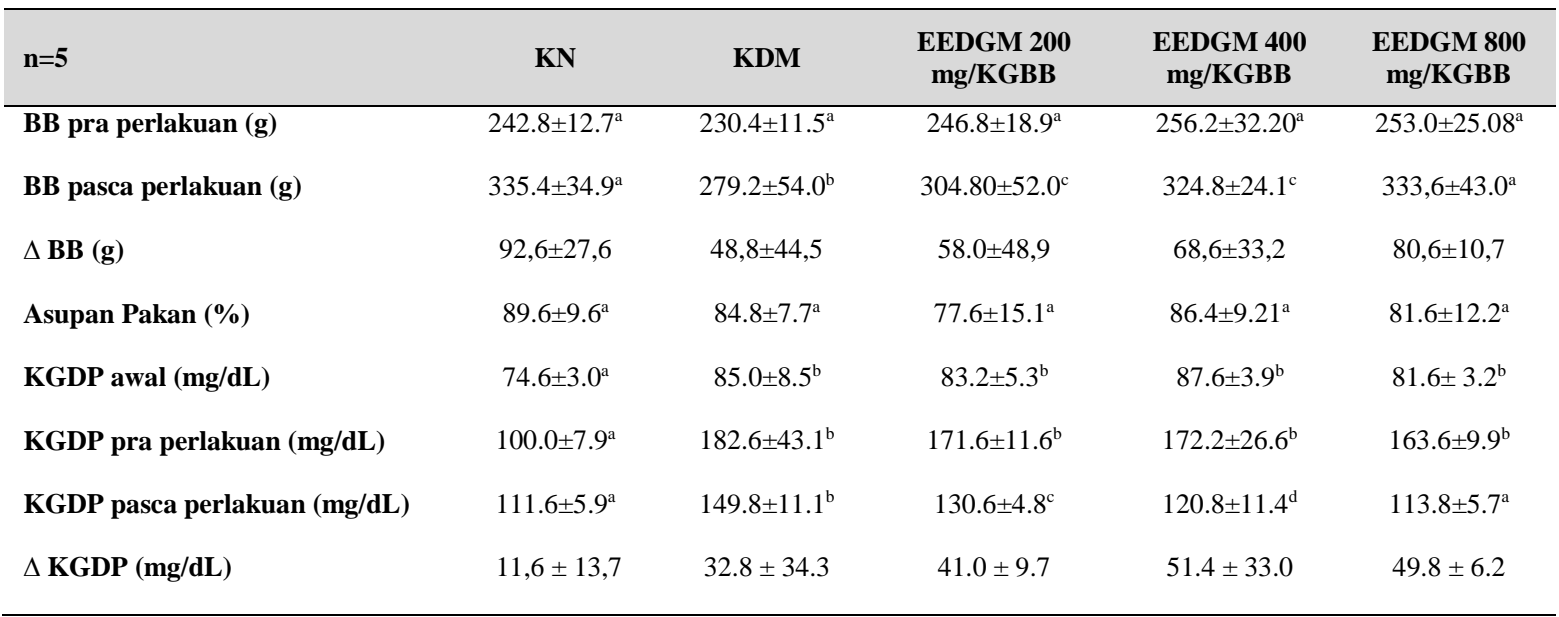

Keterangan:

Data dalam mean \pm SD. Uji statistik menggunakan One Way Anova dan Post Hoc LSD test, BB: Berat Badan, $\Delta$ BB: selisih BB post treat dan pre treat, KGDP : Kadar Glukosa Darah Puasa, KN: Kontrol Negatif, KDM: Kontrol Diabetes Melitus, EEDGM: pemberian ekstrak etanol daun gedi merah. Notasi yang berbeda menunjukkan signifikansi $(\mathrm{p}<0.05)$

Berdasarkan tabel 1, berat badan pra perlakuan relatif tidak berbeda antar kelompok $(\mathrm{p}>0,05)$. Berat badan pasca perlakuan cenderung lebih meningkat pada semua kelompok dibandingkan berat badan pra perlakuan. Kelompok EEDGM menunjukkan berat badan yang lebih tinggi dibandingkan $\mathrm{KDM}(\mathrm{p}<0,05)$, namun pada kelompok perlakuan EEDGM $800 \mathrm{mg} / \mathrm{KgBB}$ tidak terdapat perbedaan yang signifikan dengan $\mathrm{KN}(\mathrm{p}>0,05)$.

Asupan pakan terendah terdapat pada kelompok EEDGM $200 \mathrm{mg} / \mathrm{kgBB}$ dan tertinggi pada kelompok KN. KGDP pra perlakuan cenderung meningkat pada kelompok KDM dan perlakuan setelah induksi DM(p<0,05). KGDP pasca perlakuan pada kelompok EEDGM lebih kecil dibandingkan kelompok KN(p<0,05). KGDP pasca perlakuan pada kelompok KDM lebih tinggi dibandingkan $\mathrm{KN}(\mathrm{p}<0,05)$, namun pada kelompok perlakuan EEDGM $800 \mathrm{mg} / \mathrm{KgBB}$ tidak terdapat perbedaan yang signifikan dengan $\mathrm{KN}(\mathrm{p}>0,05)$.

Efek Ekstrak Etanol Daun Gedi Merah terhadap Kadar SOD Aorta Tikus Model Diabetes Melitus

Efek Ekstrak Etanol Daun Gedi Merah (Abelmoschus manihot (L.) Medik) terhadap kadar SOD aorta tikus model Diabetes dapat dilihat pada gambar 1. 


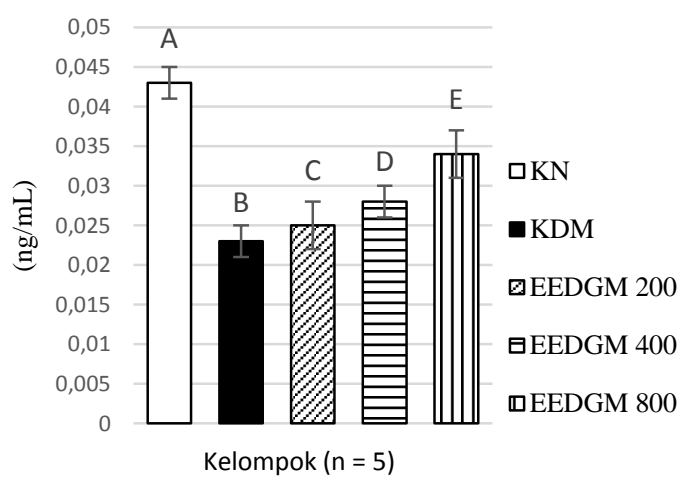

Gambar 1. Histogram kadar SOD aorta tikus model diabetes yang telah diberikan ekstrak etanol daun gedi merah

Keterangan:

Data dalam mean \pm SD. Uji statistik menggunakan One Way Anova dan Post Hoc LSD test, KN: Kontrol Negatif, KDM: Kontrol Diabetes Melitus, EEDGM 200,400,800: pemberian ekstrak etanol daun gedi merah dosis $200 \mathrm{mg} / \mathrm{kgBB}, 400$ $\mathrm{mg} / \mathrm{kgBB}$ dan $800 \mathrm{mg} / \mathrm{kgBB}$, huruf berbeda menunjukkan perbedaan signifikan $(\mathrm{p}<0,05$, LSD)

Induksi DM dengan pemberian DTLF dan STZ menurunkan kadar SOD aorta secara signifikan sekitar 50\% dibandingkan kelompok kontrol normal ( $<<0,05)$. Pemberian EEDGM dosis $200 \mathrm{mg} / \mathrm{kgBB}$, $400 \mathrm{mg} / \mathrm{kgBB}$, dan $800 \mathrm{mg} / \mathrm{kgBB}$ secara signifikan menghambat penurunan SOD aorta tikus model DM berturut-turut sekitar 10\%, 30\% dan 50\% dibandingkan KDM $(\mathrm{p}<0,05)$. Terdapat perbedaan yang signifikan antara kelompok perlakuan herbal dalam menghambat penurunan kadar SOD aorta $(\mathrm{p}<0,05)$.

Efek Ekstrak Etanol Daun Gedi Merah terhadap Kadar MDA Aorta Tikus Model Diabetes Melitus Efek Ekstrak Etanol Daun Gedi Merah (Abelmoschus manihot (L.) Medik) terhadap kadar MDA aorta tikus model Diabetes dapat dilihat pada gambar 2 .

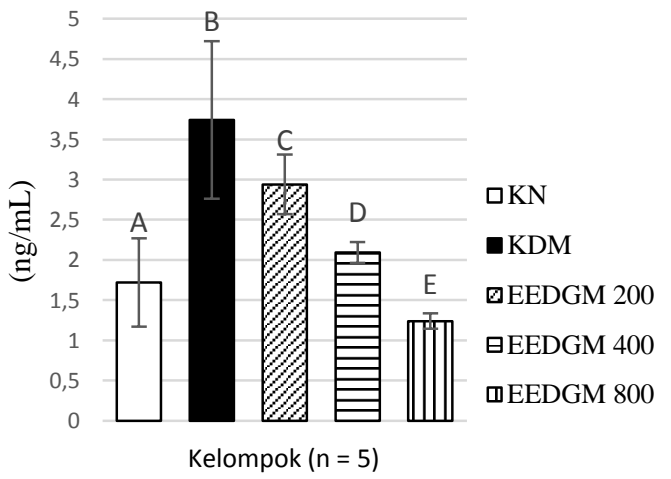

Gambar 2. Histogram kadar MDA aorta tikus model diabetes yang telah diberikan ekstrak etanol daun gedi merah

Keterangan:

Data dalam mean $\pm \mathrm{SD}$. Uji statistik menggunakan One Way Anova dan Post Hoc LSD test, KN: Kontrol Negatif, KDM: Kontrol Diabetes Melitus, EEDGM 200,400,800: pemberian ekstrak etanol daun gedi merah dosis $200 \mathrm{mg} / \mathrm{kgBB}, 400$ $\mathrm{mg} / \mathrm{kgBB}$ dan $800 \mathrm{mg} / \mathrm{kgBB}$, huruf berbeda menunjukkan perbedaan signifikan $(p<0,05$, LSD)
Induksi DM dengan pemberian DTLF dan STZ meningkatkan kadar MDA aorta secara signifikan sekitar 2 kali lipat dibandingkan kelompok kontrol normal $(\mathrm{p}<0,05)$. Pemberian EEDGM dosis $200 \mathrm{mg} / \mathrm{kgBB}, 400 \mathrm{mg} / \mathrm{kgBB}$, dan $800 \mathrm{mg} / \mathrm{kgBB}$ signifikan menurunkan MDA aorta berturut-turut $20 \%, 40 \%$, dan $70 \%$ dibandingkan KDM ( $<<0,05)$. Terdapat perbedaan yang signifikan antar kelompok dosis perlakuan herbal dalam menghambat peningkatan MDA aorta $(\mathrm{p}<0,05)$.

\section{Karakteristik Sampel}

Hewan coba yang digunakan dalam penelitian ini adalah tikus Sprague dawley jantan berusia 4-6 minggu dengan berat badan 180-200 gram. Pemilihan galur Sprague dawley dikarenakan tikus jenis ini memiliki kemampuan yang baik dalam beradaptasi dengan lingkungan dan mudah dalam perawatanya. Tikus jantan dari galur ini dipilih untuk penelitian karena tidak berpengaruh terhadap hormon

Pada kelompok EEDGM menunjukkan berat badan yang lebih tinggi dibandingkan KDM. Peningkatan berat badan diduga karena adanya kandungan zat aktif pada ektrak etanol daun gedi merah seperti flavonoid dan alkaloid. Senyawa flavonoid pada ekstrak etanol daun gedi merah diduga mampu meningkatkan berat badan dengan cara meningkatkan sensitivitas reseptor insulin dan alkaloid dengan cara meningkatkan sekresi insulin. Peningkatan sensitivitas reseptor insulin dan sekresi insulin dapat meningkatkan pemasukan glukosa kedalam sel sehingga lipolisis dihambat ${ }^{6}$. Sedangkan BB pasca perlakuan pada kelompok KDM berbeda signifikan lebih rendah dibandingkan dengan kelompok normal (KN). Hal ini disebabkan karena induksi DTLF dan STZ memicu terjadinya resistensi insulin dan penurunan sekresi insulin. Keadaan ini menyebabkan glukosa tidak dapat masuk ke dalam sel sehingga meningkatkan terjadinya lipolisis yang menyebabkan BB pasca perlakuan pada KDM lebih rendah dibandingkan $\mathrm{KN}^{11,12}$. Pada hasil pengukuran asupan pakan didapatkan penurunan nafsu makan pada KDM dibandingkan kelompok KN. Hal tersebut diduga karena komponen lipid dalam pakan sulit dicerna sehingga memperlama pengosongan lambung. Hal ini menyebabkan rasa kenyang sehingga terjadi penurunan asupan pakan pada kelompok KDM ${ }^{26}$.

Kadar Glukosa Darah Puasa (KGDP) pra perlakuan pada KDM cenderung lebih tinggi dibandingkan dengan KN. Hal ini disebabkan karena induksi dari DTLF dan STZ pada kelompok KDM memicu terjadinya resistensi insulin dan kerusakan sel $\beta$ pankreas sehingga memicu peningkatan KGDP pra perlakuan. Hal ini sejalan dengan penelitian Purnomo, 2018 bahwa induksi DTLF selama 7 minggu dan STZ $25 \mathrm{mg} / \mathrm{kgBB}$ multiple dose i.p meningkatkan glukosa darah dibandingkan dengan KN. Pemberian ekstrak etanol daun gedi merah 
(EEDGM) secara signifikan dapat menurunkan KGDP dibandingkan dengan KDM. Hal ini disebabkan karena kandungan senyawa aktif dari daun gedi merah seperti alkaloid dan flavonoid yang memicu peningkatan sekresi insulin dan sensitivitas reseptor insulin sehingga meningkatkan penyerapan glukosa ke dalam sel dan menurunkan KGDP pada tikus model $\mathrm{DM}^{6}$.

\section{Efek Pemberian DTLF dan STZ terhadap Kadar SOD dan MDA Aorta}

Induksi DTLF dan STZ secara signifikan mampu menurunkan kadar SOD dan meningkatkan kadar MDA aorta pada tikus model diabetes melitus tipe 2. Injeksi (STZ) multiple dose pada penelitian ini menyebabkan kerusakan pada sel $\beta$ pankreas sehingga menurunkan sintesis dan sekresi insulin ${ }^{13}$. Penurunan sekresi insulin memicu terjadinya hiperglikemi. STZ bekerja melalui pengalihan gugus metil dari STZ ke molekul DNA menghasilkan alkilasi DNA yang mengakibatkan kerusakan sel $\beta$ pankreas $^{13}$. Kerusakan DNA akibat STZ mengaktivasi poly ADP-ribose polimerase-1 (PARP-1) dan mengakibatkan penekanan NAD+ seluler, sehingga menurunkan jumlah ATP dan menyebabkan kematian sel-sel $\beta$ pankreas. Akhirnya terjadi penurunan sintesis insulin ${ }^{14}$. Keadaan resistensi insulin dan penurunan sintesis insulin berperan terhadap keadaan hiperglikemia.

Pemberian diet tinggi lemak (DTL) dapat menimbulkan resistensi insulin melalui peningkatan Free Fatty Acid (FFA) sehingga meningkatkan diacylgliserol (DAG) dan Protein Kinase C (PKC). PKC adalah enzim yang memfosforilasi serin pada reseptor insulin dan Insulin Receptor Substrat (IRS1 dan IRS-2). Forsforilasi serin pada IRS-1 dan IRS2 dapat menyebabkan penurunan kemampuan IRS untuk mengaktivasi PI 3 kinase, sehingga menyebabkan kinerja GLUT menurun dan reseptor insulin signalling berkurang. Sehingga terjadi resistensi insulin. Diet tinggi lemak dapat menyebabkan obesitas yang merupakan faktor risiko terjadinya diabetes melitus ${ }^{11}$.

Pemberian diet tinggi fruktosa (DTF) dapat menimbulkan resistensi insulin melalui peningkatan Free Fatty Acid (FFA). Penyerapan fruktosa dari intestinal masuk ke dalam vena porta hepatica dibantu oleh glukosa transporter 5 (GLUT-5) kemudian masuk ke dalam hepatosit melalui GLUT2. Di dalam hepatosit akan diubah menjadi fruktosa 1-fosfat oleh enzim fruktokinase, kemudian oleh enzim aldolase $B$ diubah menjadi triose fosfat. Penumpukan triose fosfat menstimulasi sintesis glikogen dan free fatty acid (FFA) dari karbon pada fruktosa melalui jalur metabolik de novo lipogenesis. Pembentukan asam lemak dari proses de novo lipogenesis yang berlebihan dapat menurunkan sensitivitas insulin sehingga terjadi resistensi insulin. Resistensi insulin memicu kondisi hiperglikemia. Kondisi ini menyebabkan sel $B$ pankreas memproduksi insulin lebih banyak.
Keadaan ini menyebabkan sel $\beta$ pankreas mengalami fatigue dan menurunkan sekresi insulin ${ }^{12}$.

Kondisi hiperglikemi akibat induksi DTLF dan STZ akan meningkatkan produksi Reactive Oxygen Species (ROS). Kondisi ini terjadi melalui 4 jalur diantaranya Protein Kinase C, Advanced Glycation End Products, Polyol Pathway dan Hexosamine Pathway. Mekanisme tersebut menghasilkan peningkatan ROS yang dapat menimbulkan kerusakan oksidatif dan dapat merusak membran lipid, DNA, dan protein pada berbagai sel dan jaringan ${ }^{3}$. Peningkatan radikal bebas memicu superoxide dismutase (SOD) untuk mengkatalisis radikal anion superoksida. SOD adalah suatu antioksidan endogen yang bekerja menghambat kerusakan oksidatif akibat radikal anion superoksida ${ }^{7}$ SOD dikenal sebagai antioksidan enzimatis dengan kofaktor ion logam seperti tembaga $(\mathrm{Cu})$, seng $(\mathrm{Zn})$, dan mangan $(\mathrm{Mn})$. SOD berfungsi sebagai katalisator reaksi dismutasi dari anion superoksida $\left(\mathrm{O}_{2}^{-}\right)$menjadi hidrogen peroksida ( $\mathrm{H} 2 \mathrm{O} 2)$ untuk mendegradasi terbentuknya radikal bebas. Karena produksi ROS yang terlalu tinggi maka sebagai konsekuensinya kadar SOD akan mengalami penurunan akibat ROS yang terlalu banyak didismutase ${ }^{7}$. Peningkatan radikal bebas tanpa diimbangi dengan antioksidan di dalam tubuh menimbulkan stres oksidatif $^{4}$. Keadaan stress oksidatif memicu peroksidasi lipid oleh radikal hidroksil dan menghasilkan produk malondialdehyde (MDA) ${ }^{15}$.

Kekurangan dari penelitian ini adalah variabel yang digunakan pada penelitian belum mewakili semua faktor-faktor yang mempengaruhi pada penelitian. Salah satu faktor tersebut adalah penilaian resistensi insulin sebagai marker untuk menilai kondisi diabetes melitus tipe 2. Sehingga pada penelitian ini perlu dilakukan uji indeks sensitivitas insulin pada hewan uji.

\section{Kadar SOD Aorta Tikus Model Diabetes Setelah Diberikan Ekstrak Etanol Daun Gedi Merah}

Pemberian ekstrak etanol daun gedi merah dapat menghambat penurunan kadar SOD aorta tikus model DM. Efek tersebut berhubungan dengan kandungan zat aktif yang berperan sebagai antioksidan dan antidiabetik dari EEDGM. Efek antioksidan EEDGM dipengaruhi senyawa polifenol, flavonoid (quercentin), dan saponin. Senyawa aktif polifenol berperan sebagai antioksidan yang mampu mengurangi stres oksidatif dengan mendonorkan atom hidrogen dari kelompok atom hidroksil $(\mathrm{OH}-)$ kepada anion superoksida, reaksi ini menghasilkan senyawa baru yang lebih stabil $^{6,19}$. Senyawa flavonoid juga mampu bekerja dengan cara meningkatkan kemampuan ekspresi antioksidan endogen seperti SOD, katalase dan glutation peroksidase ${ }^{20}$. Pada penelitian Liu 2006, senyawa flavonoid yang bekerja sebagai scavenger radikal bebas adalah flavonol dan flavone. Hal ini diperkuat juga dari penelitian Mercy 2015, bahwa 
senyawa aktif dari flavonoid yaitu senyawa quercetine memiliki aktivitas antioksidan yang tinggi sebagai scavenger radikal bebas. Senyawa saponin bersifat sebagai antioksidan yang bekerja sebagai scavenger radikal hidroksil dan superhidroksil, sehingga menurunkan jumlah radikal bebas $^{6}$. Hal ini sesuai dengan penelitian yang dilakukan Nobertson et al, 2018 bahwa kandungan senyawa aktif ekstrak etanol daun gedi merah memiliki aktivitas antioksidan yang tinggi dan menurunkan radikal bebas ${ }^{21}$. Penurunan radikal bebas akan menekan penggunaan antioksidan endogen seperti SOD aorta, sehingga kadar SOD dapat dipertahankan. Hal ini sesuai dengan penelitian Khalidiyah et al, 2020 (unpublished) bahwa pemberian EEDGM mampu menghambat penurunan kadar SOD jantung tikus model DM.

Mekanisme secara tidak langsung dalam menghambat penurunan SOD dengan mekanisme antidiabetik. Potensi antidiabetik pada ekstrak etanol daun gedi merah diperankan oleh senyawa aktif antara lain alkaloid, flavonoid, saponin, dan $\operatorname{tanin}^{6,17}$. Senyawa alkaloid bekerja dengan mekanisme regenerasi sel $\beta$ pankreas, sehingga dapat meningkatkan insulin ${ }^{6}$. Senyawa flavonoid berperan sebagai antidiabetik melalui mekanisme meningkatkan sensitivitas reseptor insulin pada $\mathrm{sel}^{6}$. Pada penelitian Pan, et al. 2017, senyawa flavonoid yang terkandung dalam daun gedi merah antara lain hyperoside, isoquercitrin, dan rutin. Saponin memperbaiki kondisi hiperglikemia dengan cara menghambat aktivitas enzim alfa glukosidase, yaitu enzim saluran pencernaan yang dapat mengubah karbohidrat menjadi glukosa ${ }^{6,17}$. Tanin berfungsi sebagai astrigens yang dapat mengerutkan membran epitel usus halus sehingga mengurangi penyerapan sari makanan sehingga dapat menghambat asupan gula dan laju peningkatan gula darah tidak terlalu tinggi ${ }^{17}$. Potensi antidiabetik dari daun gedi merah terbukti dengan penurunan KGDP pasca perlakuan yang menurun pada kelompok pemberian herbal EEDGM. Inhibisi dari keadaan hiperglikemia akan menekan produksi radikal bebas sehingga menekan penggunaan SOD sebagai pendismutase anion superoksida sehingga menghambat penurunan kadar SOD aorta. Hal ini sejalan dengan penelitian yang dilakukan Marcedes (2017) bahwa ekstrak etanol daun gedi merah memiliki potensi mengendalikan peningkatan kadar glukosa darah pasca induksi $\mathrm{DM}^{17}$, sehingga menghambat penurunan kadar SOD aorta.

Pada penelitian ini didapatkan pemberian EEDGM dosis $800 \mathrm{mg} / \mathrm{kgBB}$ memiliki efek menghambat penurunan kadar SOD aorta lebih kuat dibandingkan dosis $200 \mathrm{mg} / \mathrm{kgBB}$ dan 400 $\mathrm{mg} / \mathrm{kgBB}$. Hal ini sesuai dengan teori farmakologi, yaitu semakin tinggi dosis yang diberikan semakin tinggi pula efek yang ditimbulkan. Kadar SOD kelompok kontrol normal pada penelitian ini didapatkan 43,78 $\pm 2,69 \mathrm{pg} / \mathrm{mL}$. Hasil tersebut tidak jauh berbeda dengan nilai SOD kelompok kontrol normal pada penelitian Cheng (2018) yang bernilai
$58,03 \pm 2,94 \mathrm{pg} / \mathrm{mL}^{23}$. Hal tersebut membuktikan bahwa kadar kontrol normal SOD aorta tikus tidak bermasalah. Pemberian EEDGM dosis 800 $\mathrm{mg} / \mathrm{kgBB}$ belum mampu meningkatkan kadar SOD aorta setara dengan kontrol normal. Hal ini diduga dosis $800 \mathrm{mg} / \mathrm{kgBB}$ belum adekuat dalam meningkatkan kadar SOD setara dengan kontrol normal, sehingga perlu dilakukan penelitian dengan dosis yang lebih tinggi dari $800 \mathrm{mg} / \mathrm{kgBB}$.

\section{Kadar MDA Aorta Tikus Model Diabetes Setelah Diberikan Ekstrak Etanol Daun Gedi Merah}

Pemberian ekstrak etanol daun gedi merah pada penelitian ini dapat menghambat peningkatan kadar MDA aorta tikus model DM. Efek tersebut berhubungan senyawa aktif ekstrak etanol daun gedi merah sebagai antioksidan dan antidiabetik. Efek antioksidan EEDGM dipengaruhi senyawa flavonoid, saponin dan polifenol dengan mekanisme menangkal radikal hidroksil dan superhidroksil sehingga dapat menghambat terjadinya peroksidasi lipid dan menghambat peningkatan $\mathrm{MDA}^{6}$. Senyawa flavonoid berperan sebagai pengkelat ion $\mathrm{Fe}^{2+}$ yang diperankan oleh senyawa aktif yaitu quercentine. Ion $\mathrm{Fe}^{2+}$ sangat efektif sebagai prooksidan dan dapat menginisiasi peroksidasi lipid. Interaksi ion $\mathrm{Fe}^{2+}$ dengan hidrogen peroksida pada sistem biologi dapat membentuk radikal hidroksil yang sangat reaktif. Proses ini dapat ditunda dengan mengkelat ion $\mathrm{Fe}^{2+}$ dan menghambat terjadinya peroksidasi lipid sehingga produk MDA tidak dihasilkan ${ }^{19}$. Radikal hidroksil bersifat sangat toksik, mengganggu permeabilitas sel, dan dapat memperoksidasi lipid membran sel untuk menghasilkan MDA. Jika pembentukan radikal hidroksil dapat dihambat maka MDA tidak dapat dibentuk dan kerusakan sel tidak terjadi ${ }^{19}$. Efek Zat aktif dari ekstrak etanol daun gedi merah termasuk dalam antioksidan eksogen yang berperan untuk menangkal radikal bebas. Hal ini sesuai dengan penelitian sebelumnya yang dilakukan Khalidiyah et al, 2020 (unpublished) bahwa kandungan senyawa aktif ekstrak etanol daun gedi merah memiliki aktivitas antioksidan yang dapat menurunkan kadar MDA jantung tikus model DM tipe 2.

Kandungan senyawa aktif dari daun gedi merah berperan secara tidak langsung dalam menghambat peningkatan kadar MDA dengan memperbaiki keadaan hiperglikemia, sehingga menghambat terbentuknya radikal bebas seperti yang dijelaskan sebelumnya. Keadaan ini menghambat terjadinya stres oksidatif sehingga tidak terjadi peroksidasi lipid akibat radikal bebas yang menghasilkan $\mathrm{MDA}^{6,15}$.

Pada penelitian ini didapatkan pemberian EEDGM dosis $800 \mathrm{mg} / \mathrm{kgBB}$ memiliki efek menghambat peningkatan kadar MDA aorta lebih kuat dibandingkan dosis $200 \mathrm{mg} / \mathrm{kgBB}$ dan 400 $\mathrm{mg} / \mathrm{kgBB}$. Hal ini sesuai dengan teori farmakologi, yaitu semakin tinggi dosis yang diberikan semakin tinggi pula efek yang ditimbulkan. Kadar MDA kelompok kontrol normal pada penelitian ini 
didapatkan 1,72 $\pm 0,55 \mathrm{ng} / \mathrm{mL}$. Hasil tersebut tidak jauh berbeda dengan nilai MDA kelompok kontrol normal pada penelitian Santoso (2018) yang bernilai $1,95 \pm 0,22 \mathrm{pg} / \mathrm{mL}^{24}$. Hal tersebut membuktikan bahwa kadar kontrol normal MDA aorta tikus tidak bermasalah. Pemberian EEDGM dosis 800 $\mathrm{mg} / \mathrm{kgBB}$ menurunkan kadar MDA sampai dibawah kontrol normal, diduga pada dosis EEDGM 800 $\mathrm{mg} / \mathrm{kgBB}$ terjadi kematian sel akibat toksisitas dari dosis tersebut sehingga jumlah MDA yang dihasilkan lebih rendah dari kontrol normal, maka perlu dilakukan penelitian uji toksisitas pada herbal uji.

\section{KESIMPULAN}

1. Pemberian DTLF dan STZ menurunkan kadar SOD dan meningkatkan kadar MDA aorta tikus model DM

2. Pemberian ekstrak etanol daun gedi merah menghambat penurunan kadar SOD aorta tikus model DM

3. Pemberian ekstrak etanol daun gedi merah menghambat peningkatan kadar MDA aorta tikus model DM

\section{SARAN}

1. Melakukan uji indeks sensitivitas insulin.

2. Perlu dilakukan penelitian lebih lanjut dengan menggunakan dosis lebih besar dari 800 $\mathrm{mg} / \mathrm{kgBB}$ pada hewan coba

3. Perlu dilakukan uji toksisitas pada herbal uji.

\section{UCAPAN TERIMAKASIH}

Terimakasih disampaikan kepada Ikatan Orangtua Mahasiswa (IOM) dan Fakultas Kedokteran Universitas Islam Malang karena telah membantu pendanaan dalam penelitian ini.

\section{DAFTAR PUSTAKA}

1. Carrillo-Sepulveda MA, Matsumoto T, Nunes KP, Webb RC. Therapeutic implications of peptide interactions with G-protein-coupled receptors in diabetic vasculopathy. Acta Physiol. 2014;211:20-35.

2. Kementrian Kesehatan RI. " Penyakit Jantung Penyebab Kematian Tertinggi, Kemenkes Ingatkan CERDIK" . 2017 www.depkes.go.id/article/view/17073100005/p enyakit-jantung. Diakses tanggal 12 Juli 2020

3. Giacco, Ferdinando, and Michael Brownlee. "Oxidative stress and diabetic complications." Circulation, 2010, research 107.9, 1058-1070.

4. Li Sha, Hong Ming, Hor-Yue Tan, Wang Ning, Feng Yibin. Insights into the role and interdependence of oxidative stress and inflammation in liver diseases. Oxidative Medicine and Cellular Longevity, 2016.
5. Fukai T, Ushio-fukai M. Superoxide Dismutases: Role in Redox Signaling, Vascular Function, and Diseases. Mary Ann Liebert, Inc. 2011;15(6).

6. Tandi Joni, Muthi'ah, Yuliet, Yusriadi. Efektivitas Ekstrak Daun Gedi Merah terhadap Glukosa Darah, Malondialdehid, 8-HdroksiDeoksiguanosin, Insulin Tikus Diabetes. Journal of Tropical Pharmacy and Chemistry, 2016, 3.4: 264-276.

7. Nurfadilah, Lianda Destrin; Nurainiwati, Sri Adilla; Agustini, S. M. Pengaruh pemberian minyak deep frying terhadap perubahan histopatologi jantung tikus putih (Rattus novergicus strain Wistar). Saintika Medika: Jurnal Ilmu Kesehatan dan Kedokteran Keluarga, 2017, 9.1: 54-58.

8. Fattah Yusuf, Kamu Vanda, Runtuwene Max, Momuat Lidya. Identifikasi Barcode Tumbuhan Gedi Merah (Abelmoschus manihot L. medik) dan Gedi Hijau (Abelmoschus moschatus) Berdasarkan Gen matK. Jurnal MIPA, 2014, 3.2: 120-124.

9. Murwani, Sri; Ali, Mulyohadi; Muliartha, Ketut. Diet aterogenik pada tikus putih (Rattus novergicus strain Wistar) sebagai model hewan aterosklerosis. Jurnal Kedokteran Brawijaya, 2013, 22.1: 6-9.

10. Xiang Xuesong, Wang, Zhu, Bian, Yang. Dosage of streptozocin in inducing rat model of type 2 diabetes mellitus. Wei sheng yan jiu= Journal of hygiene research, 2010, 39.2: 138-142.

11. Boden, Guenther; Laakso, Markku. Lipids and glucose in type 2 diabetes: what is the cause and effect?. Diabetes care, 2004, 27.9: 2253-2259.

12. Wulansari, Devyani Diah; Wulandari, Devyana Dyah. Pengembangan Model Hewan Coba Tikus Diabetes Mellitus Tipe 2 dengan Induksi Diet Tinggi Fruktosa Intragastrik. MPI (Media Pharmaceutica Indonesiana), 2018, 2.1: 41-47.

13. Nugroho, A. E. Hewan Percobaan Diabetes Mellitus: Patologi Dan Mekanisme Aksi Diabetogenik. Biodiversitas, 7(4), 378-382. (2006).

14. Ghasemi, Asghar; Khalifi, S.; Jedi, S. Streptozotocin-nicotinamide-induced rat model of type 2 diabetes. Acta Physiologica Hungarica, 2014, 101.4: 408-420.

15. Ayala, Antonio; Muñoz, Mario F.; Argüelles, Sandro. Lipid peroxidation: production, metabolism, and signaling mechanisms of malondialdehyde and 4-hydroxy-2nonenal. Oxidative medicine and cellular longevity, 2014, 2014.

16. El-Beltagi, Hossam S.; Mohamed, Heba I. Reactive oxygen species, lipid peroxidation and antioxidative defense mechanism. Notulae Botanicae Horti Agrobotanici Cluj-Napoca, 2013, 41.1: 44-57.

17. Marcedes, Agustina. Aktivitas Antidiabetes Kombinasi Ekstrak Daun Gedi Merah Dan Daun Semak Bunga Putih Tikus Induksi 
Streptozotocin. Farmakologika: Farmasi, 2017, 14.2: 159-166.

18. Pan, Xinxin, et al. Dynamic changes of flavonoids in Abelmoschus manihot different organs at different growth periods by UPLCMS/MS. Journal of Chromatography B, 2017, 1059: 21-26.

19. Teroreh Mercy, Rahardjo, Murdiati. Ekstraksi daun gedi (Abelmoschus Manihot L) secara sekuensial dan aktivitas antioksidannya. Agritech, 2015, 35.3: 280-287.

20. Ambu, Yuliati Lika. Pengaruh Ekstrak Etanol Daun Gedi Merah (Abelmoschus Manihot L. Medik) Terhadap Penurunan Kadar Bun Dan Kreatinin Serum Pada Tikus Diabetes Nefropati Yang Diinduksi Streptozotocin-Nikotinamid. 2018. PhD Thesis. Universitas Setia Budi Surakarta.

21. Nobertson, Ronaldy; Indah, Novita Puspita; Kenta, Yunlis Silintowe. Uji Aktivitas Antioksidan Ekstrak Etanol Daun Gedi Merah (Abelmoschus Manihot (L).) Palu Sulawesi Tengah. Farmakologika: Jurnal Farmasi, 2018, 15.1: 63-71.

22. Adyttia, Asri; Untari, Eka Kartika;Wahdaningsih, Sri. Efek ekstrak etanol daun Premna cordifolia terhadap malondialdehida tikus yang dipapar asap rokok. Pharmaceutical Sciences and Research (PSR), 2016, 1.2: 104-115.

23. Cheng, et al. Significance of malondialdehyde, superoxide dismutase and endotoxin levels in Budd-Chiari syndrome in patients and a rat model. Experimental and Therapeutic Medicine, 2018, 16.6: 5227-5235.

24. Santoso . Potensi Ekstrak Biji Kedelai (Glycine max), Rimpang Jahe (Zingiber officinale) dan Kombinasinya Terhadap Kadar Malondialdehida (MDA) Serum dan Ketebalan Dinding Aorta pada Tikus Model Diabetes. Jurnal Bio Komplementer Medicine, 2019. 